\title{
Kosovo and the end of the legitimate warring state
}

Humanity does not gradually progress from combat to combat until it arrives at universal reciprocity, where the rule of law finally replaces warfare; humanity installs each of its violences in a system of rules and thus proceeds from domination to domination. ${ }^{1}$

\section{Introduction}

One of the starting-points of this volume is that the Weberian principle of the state as possessing a legitimate monopoly on violence is fading. Sovereigns no longer hold this monopoly; it now belongs to the international community. This chapter investigates the effects of this fading of legitimacy. If war is seen as the extension of politics by other means, then there are three crucial questions to be asked about its legitimacy. First, which actors are seen as legitimate wagers of war, and by whom? Second, over what kinds of issues is it legitimate to intensify politics by going to war (ius ad bellum)? And, third, what are the legitimate ways of waging war?

Expanding on a framework suggested by the Copenhagen School of international relations, this chapter argues that the Kosovo war is a crucial part of two on-going shifts. First, it is increasingly time that the actors going to war are states acting in alliance - and in the name of humanity. Second, war is legitimised less by reference to the safeguarding of state citizens and their well-being, and more in terms of infringements on human rights. It is further argued that one vital precondition for this shift is that, with the demise of the left-right divide which for the last 200 years structured politics, there is only one camp left in possession of the resources to legitimately represent 'humanity'. In Kosovo, the states going to war as the NATO Alliance represented themselves as 'humanity', the implication being that Serbia was cast as an enemy not only of human rights but of humanity as such. There is an irony here, as the kind of state infringement which NATO worked on Serbia 
by going to war over its internal politics was itself considered a casus belli as recently as twenty years ago. In Kosovo, it was actually Serbia that embodied traditional thinking about the legitimacy of war, and NATO the break with that tradition. Serbia appears, therefore, as a living reminder of how the nation state, which was considered normal not too long ago, used to act.

\section{The Copenhagen School and violisation}

It is unlikely that war as a form of intensified conflict between different human collectives will disappear. Sometimes such conflicts result in the use of violence, which is itself met with violence. As a consequence, war becomes a reality, and organised violence forces itself into our repertoire of social possibilities. War is a continuation of politics by other means.

Politics is, among other things, an ongoing negotiation about who 'we' are. Since a 'we' is untenable without a relationship to some group, a 'they,' the political question of who 'we' are is in fact a matter of separating 'us' from 'them'. To use Carl Schmitt's formulation, it is a question of separating friend from enemy. ${ }^{2}$ In light of this, the question may be recast as one of how certain symbolic economies - certain packages of elements of a story of self as well as the relations between them - work to produce war as an outcome of ever more sharply defined friend-enemy relations.

Over the last decade, the Copenhagen School has concentrated on expanding the referents of security from states and individuals to society, and on analysing how political concerns come to be treated as security concerns. As Ole Wæver, in the published version of the 1988 paper that launched the concept of 'securitisation', put it: 'State security has sovereignty as its ultimate criterion, and societal security has identity. Both usages imply survival. A state that loses its sovereignty does not survive as a state; a society that loses its identity fears that it will no longer be able to live as itself. ${ }^{3}$ A major problem with this dichotomisation (which, I hasten to point out, definitely has its uses in opening up the debate on the referents of security) is that in fact it has a detrimental effect on questions of war. The declaration of war, after all, is an activity where states still play a crucial role. While societies and society-level groups may continue to be active in a number of ways, both before and after the declaration of war, interesting grey areas emerge when a state's idea of itself can no longer be easily represented.

The Copenhagen School argues that what it refers to as securitisation can be thought of as an extension of politicisation:

[I]ssues become securitized when leaders (whether political, societal, or intellectual) begin to talk about them - and to gain the ear of the public and the state - in terms of existential threats against some valued referent object. Securitization can thus be seen as a more extreme version of politicization. It is the intersubjective establishment of an existential threat with a saliency 
sufficient to have substantial political effects. In theory, any public issue can be located on the spectrum ranging from non-politicized (meaning that the state doesn't deal with it, and it is not in any other way made an issue of public debate and decision); through politicized (meaning that the issue is part of public policy, requiring government decision and resource allocation or more rarely some other form of communal governance); to securitized (meaning that the issue is presented as an existential threat requiring emergency measures, and justifying actions outside the normal bounds of political procedure). In principle, the placement of issues on this spectrum is open; depending on circumstances, any issue can end up on any part of the spectrum. ${ }^{4}$

Politicisation is a matter of inscribing certain differences between self and other with meaning as the defining diacritics of self and other. That is, certain differences, which until now have not been activated as part of the political, are being politicised. This makes it possible, retrospectively, to talk about them as having been 'non-politicised' before they were 'politicised'.

Securitisation, on the other hand, includes the added burden of defining what constitutes the security politics of a certain human collective in establishing political diacritics. Wæver, who subscribes to a Schmittian definition of the political as a question of separating 'friend' from 'foe' (see above), tends to think about security as existential or ontological politics - that is, the political at its most political: the questions of telling friend from enemy, the defining of who 'we' are and, functionally, the threats to who 'we' are.

The theorem proposed is thus one in which issues can be non-politicised, politicised or securitised, and for which there exist four processes, known respectively as politicisation, de-politicisation, securitisation and desecuritisation. An identity, for example, may be securitised by speech which inscribes that identity with meaning in terms of security politics, and may also be de-securitised by speech unsubscribing such a representation.

Emphasising the importance of speech to the process of securitisation, the Copenhagen School highlights the constructed intrasubjective character of the concept of security and hence also of the modus operandi of security politics. Using the concept of discourse in order to de-differentiate words and action, the Copenhagen School has advanced convincing work. The outbreak of war may, of course, also be conceptualised as a speech act, such as the case when the statement 'I hereby declare war' is indeed to go to war (provided one's institutional station and preparations are appropriate). The actual waging of war, however, requires more than speech declaring war: it requires the use of force, or a violisation of politics. ${ }^{5}$ Waging war is, by definition, a question not only of speech, but of actions. A crucial role in war involves the act of killing, and, more generally, the acts of violence which literally inscribe the will of one collective onto the physical bodies making up the body politic of another human collective. There is a reason why the number of people killed, be that 317 or 1,000 , almost always becomes the defining trait of what war is. ${ }^{6}$ 
Actually, there are intimations inside the Copenhagen School itself that a speech act perspective is hardly sufficient as a focus of political analysis. For example, Wæver quotes Clausewitz to the effect that '[w]ar is an act of violence pushed to its utmost bounds'. When war-like activity does not include acts of violence it is referred to by modifiers, such as 'a war of position' and 'a cold war'. In order to link the work of the Copenhagen School to the outbreak of war, it may be useful to differentiate the concept of securitisation, reserving that concept for those acts of speech which perform the tasks Barry Buzan, Wæver and others have assigned to it, and subsequently adding a new category for cases where large-scale violence is actually in evidence.

We can best apply the Copenhagen School's framework to this question by defining the threshold between securitisation and violisation as the point of the outbreak of war itself (violence on a certain scale), rather than at the point where an individual dies. This is not to deny that a certain identity is already violised in situations such as when arson is being committed against a refugee asylum, resulting in death; it is simply to acknowledge that the question of scale must be addressed. It is not societal security and the identitysociety nexus that are under consideration here, but identity and war, and I will argue that this question still implicates the state very directly. Thus, for this purpose, societal violence, which is not intended to impinge on the question of state borders, may be bracketed, and attention focused on cases where the issue is the representation of states. In this way, Clausewitz's formulation of war as the continuation of politics by other means can be classified, both directly and indirectly, within the Copenhagen School framework of politicisation and securitisation. If we add the category 'violised' to the three already in circulation, and introduce the two corresponding processes of 'violisation' and 'de-violisation,' we get the following extended continuum: non-politicised-politicised-securitised-violised.

An obvious case to which the proposed extended continuum could be applied is the war in Kosovo. ${ }^{8}$ We have in this situation a number of cases where national identities became not only securitised but violised. Serb and Croatian national identities, Bosniak political identity and Muslim religious identity provide suitable examples. By contrast, Macedonian and Albanian ethnic identities were securitised but not violised (again, the use of the suggested term 'violised' applying only when violence takes place on a certain scale). It would be interesting indeed, if it could be demonstrated that the outbreaks and non-outbreaks of war are usefully analysed in terms of violisation of identity. If it turns out that the structure of identity was not a crucial factor in the outbreaks of these wars, then this would also prove insightful.

\section{War as legitimate violisation of politics}

A different aspect, indeed a crucial concern, of the war in Kosovo is the problematique of who can legitimately wage war. For the last 500 or so 
years, this function has fallen to states, and states have orchestrated a legal discourse which consecrates their going to war in certain circumstances, over certain issues. When fought by states in accordance with this ius ad bello, war has been a legitimate form of violisation (inside the international law discourse). In Kosovo, however, two phenomena may be observed. First, although in accordance with the discourse of international law states were still the actors to go to war, the relevance of this discourse for the work of legitimisation that was carried out by the instigators of war was not deemed to be sufficiently wide ranging for it to stand alone. Additional legitimacy was sought by stipulating that it was an alliance of states which went to war, and that the war itself could be seen as contributing to a change in the discourse of international law, and not simply as a case of following its rules. In this way, the war in Kosovo was represented as being constitutive of a new era. This change in who could legitimately wage war (alliances of states acting as self-proclaimed representatives of humanity) was intimately linked to the question of over what issues it is legitimate to go to war (alleged infringements of human rights, that is, the rights of the constituent members of humanity).

This constituted a breach with an epochal tradition. In seventeenthcentury Europe, the framework of spiritual life - Protestant or Catholic was central when defining military goals. In the eighteenth century wars evolved around disputes over inheritance and land, whereas the Napoleonic Wars added the type of regime - republican or monarchic - to the matters of contention. An illustrative example of this tendency appears in the memoirs of the Yugoslavian communist Milovan Djilas, in which he refers to a conversation with Stalin in $1945 .{ }^{9}$ This war is not like other wars, Stalin said to Djilas; the conqueror spreads his political system as far as his men can go. It cannot be any other way. The major point here for our purposes is the plurality of actors involved in constituting the major conflict line at any one time in the history of the European states' system: two during the seventeenth century, many during the eighteenth and nineteenth centuries, again two during the twentieth century. Now, with the United States being the only superpower around, the so-called 'unipolar moment' has arrived but it is also a unipolar moment when it comes to the number of systemsconstituting identity projects available. There is only one: liberal globalisation - and its opponents. This is an important condition for how human rights can emerge as a key legitimising resource, and so I return to this problematique below.

The Kosovo war defines the epoch exactly because it focused on the simultaneously existing conflict lines upon which politics is constituted. Since the end of the seventeenth century political life has centred around two great themes; the economic division between classes, and the question about which community in the nation the state rests upon. There is a tension between these two considerations. The existence of classes, understood as 
groups of people with different relations to the means of production, gave rise to divisions within the state. Today's European party system is still, first and foremost, the result of the previously existing class struggle about the economic distribution of wealth. The right-left axis was the political framework of industrial society. Conservative, liberal and socialist ideologies spoke to a reality dominated by the agencies of social classes clear enough that one could talk about a natural categorisation of people as between 'left' and 'right'. Politics needed this type of categorisation in order to operate. Politics is both a conflict and an arrangement to facilitate the solution to that conflict; the order is etymologically bound to the Greek polemos, war.

However, politics can also be traced to another Greek word, polis. In our context the point to retain is that politics turns itself around conflict, and the existence of the city state is dependent on the ability to restrict or apply this notion to the community. Therefore it is not accidental that the emergence of industrial society had as its accompaniment the emergence of the nation. While industrial society established new social divisions, casting worker against bourgeoisie, nationalism offered both groups a new community to which they could attach themselves. This was a community that bound them together and gave them a framework within which they could quarrel about material goods without experiencing the conflict as if they were two wholly different groups.

Between socialism and nationalism a connection was thereby established, one that served a complementary purpose. As we know, this constellation of classes and nations gave rise to two programmes of modernisation: communism, which would solve the problem through the elimination of classes, and nationalism, which would solve the problem by inserting political parentheses around the classes. The Cold War was the end-point for this development, in two respects. In the West the connection between the classes and the means of production dissolved. The struggle between socialism and capitalism, between East and West, was portrayed as a struggle between classes. In the modern West, however, the proletariat no longer exists as a production community, and the Soviet State as the kernel in the proletariat's own international order has disappeared. The carpet has been taken away from under the feet of the main principle of the organisation of politics, both at the national and at the international level.

This can of course be celebrated. It is potentially liberating for politics that the principles of the old order are disappearing. But the end of the Cold War had a second less welcome consequence. As was earlier maintained, politics needs conflict in order to function: the Cold War evolved around the idea of conflict and of conflict solution. Conflicts must be arranged in circumstances and around fundamental dividing lines that can be disputed for a long time. The right-left axis served as such a mechanism, until recently, for both the national and the international order. But what happens when this axis no longer exists in the same form as before? 
With the extinction of the right-left axis, nationalism once again stands alone. The historical nationalism was an ideology, which worked as the political foundation of the right-left matrix, yet nationalism is now itself about to become the matrix for political life. The political struggle, which really caused problems, was not formulated as an economic redistribution question, but as a question about who we are, and it is exactly this question that nationalism has an answer for. In this context it is not a coincidence that the Balkan wars of the 1990s in the former Yugoslavia were fought out directly between ethnic groups, whereas the previous civil conflict, in the wake of the Second World War, had been fought out between proletarian and middle-class partisans. It follows that, in order to mediate between these ethnic tensions, one needs a multi-ethnic rhetoric, and no longer a class rhetoric. Therefore, resistance to war developed first and foremost as a programme in favour of a common multi-ethnic society and against nationalism (and not, as it did fifty years ago in the case of the communist partisans, as a class rhetoric).

This same pattern can be identified in the international context. The drama being enacted in the Maghreb can be portrayed as a struggle between land and town, between proletariat and town elites, but it is formed in principle as a struggle between the local and the global. To quote a wellknown book title, it is a case of 'Jihad vs. McWorld'. ${ }^{10}$ And these two political powers work together, like all constellations, in order for politics to function. The so-called fundamentalist Islamic opposition in the Maghreb, and the politicians who mobilise ethnicity in the former Yugoslavia, are reacting to, among other things, increasing globalisation. And these reactions take, above all, a national identity. The Jihad, at its starting-point, was inextricably connected to the idea of a universal religion, in itself a form of essentialism, which has evolved historically to take on key nationalist traits. Globalisation has evolved as a threat to this nationalism, a nationalism that is now arming itself to fight against 'post-nationalism'. Here we have the new main axis, one which will order our political lives in the future.

Reactions against globalisation of course vary. What they have in common, however, is a local support for the local nation, which you find within many groups. Nation states in Europe were similar - and the bearers of that designation thought of themselves as being of a kind - because they all adhered to a common idea, namely that those who shared a cultural community should also share a political community. They had a project in common, even if they did not have a common project. The same may be said about today's opposition to integration and globalisation in the name of the classical nation state. Furthermore, in Europe, given that the European Union is a reality, the structural similarity between the traditional platforms from which the EU is being composed make for a structural conflict almost everywhere. Those who welcome globalisation also, as a rule, welcome integration, whereas those who oppose the one generally oppose the other as well. 
If national-post-national as the main political axis has replaced the rightleft axis, then we will see immediate negative consequences influencing the potential for constructing a consensus. As long as the right-left axis predominated, the main concern within politics was with economic distribution. Distribution could be ordered by a medium eminently divisible: money. Therefore, the so-called class compromises could be operationalised by the redistribution of money. Furthermore, it was possible to operate with a far-reaching social mobility. The adherence to the notion of class could also serve as a mechanism for manipulation. For example, one could change the factors determining one's class: position, language, address, etc. Ethnic belonging, however, is not so easy to change. The markers that define ethnic identity can be difficult to manipulate. How is it possible to change one's skin colour, for example? The colour of skin cannot be changed. ${ }^{11}$ It can only be acknowledged as more or less politically relevant.

If nationalism is determining politics, and if nationalism manifests itself in such a way that people with a certain colour cannot be a member of that nation, then the outlook for social mobility is extremely marginal. And yet, at the same time, there is no obvious medium to be used so as to reach compromises between different ethnic groups, the same way that money could be used between classes. Money can change one's job, language and address, but not one's skin colour. Classes used to be socially complementary: where purges took place within certain classes, as in the Soviet Union, the whole society deteriorated as a result. Ethnic groups are not complementary in themselves. Ethnic cleansing can be carried out without the society immediately collapsing functionally. (As the Czech example shows, however, ethnic cleansing can produce long-term morally destructive effects: one is still troubled long after the purge of the Sudeten-Germans.)

To sum up: liberal globalisation is left as the only political programme with a worldwide appeal. It feeds opposition, but that opposition takes local forms, and has so far taken the shape of negations of globalisation (ethnic and religious revivalism, nationalism, etc.) What shape globalisation will take, and how effectively it will spread, are not issues here. The claim I wish to posit is that globalisation constitutes a major precondition for how, in the Kosovo war, NATO could so easily represent itself as the guardian of human rights and, by extension, pose even as the representative of humanity as such. There simply was no major force around to issue a credible counter-claim.

\section{The ontologification of war}

War is a matter of who we are and how we are supposed to continue to exist. These aspects of war can be more or less central, possessing a radically different meaning for each of the two sides participating in a conflict. 
The stronger one side feels towards the fact that 'we' can no longer be 'ourselves' if 'we' lose the war, the more fundamental a conflict is perceived. We have, from ancient Greece, several examples of how defeat in war meant that women and children were taken as slaves and the men executed. The rationale for some wars is thereby still the physical existence of one of the combatants. It is rarely so radical, but the American tradition to demand the enemy's 'unconditional surrender', is a reminder that such absolutism is still strongly evident in the thinking of our time. One can imagine a spectrum running from Hegel's approach to war - as a situation where right stands against right - to the (mainly) Catholic tradition of 'just war', in which it is perceived that one side is fighting for the good, while the other is cast as evil. ${ }^{12}$

Developments in the 1990s indicate that we are moving towards this latter understanding of war. The notion of a 'just war' was once again raised as part of the discussion. This perspective has certain advantages to it, mainly because it offers us an opportunity to talk about war in such a way that moral aspects are emphasised. The danger of this perspective, however, is that one can easily be led to demonise the enemy. Just war becomes 'holy' war. Not least where the legal discourse is concerned, Kosovo may point in the direction of an undermining of the adversarial head of state's legitimate position. Previously, one looked upon the opposing head of state as symbolic of the adversary. This was the person who, if the surrender was not unconditional, was to become an important negotiating partner. Whereas today, referring to the international order, it is possible to issue a warrant for an arrest if the head of state does not seem sympathetic. War becomes more a question of good versus bad, and less of a way to settle disputes between two contradictory laws. Kosovo demonstrated this trend.

One could say a lot of good things about moral commitment to a just war and to the evolution of humanitarian law concerning war crimes. After Auschwitz, the GULag and Srebrenica, it is difficult to defend a point of view saying that there is no evil in politics. There are situations in which it is legitimate to talk about an evil opponent. But, although it is tempting to succumb to the passing of such a judgement, the act must be postponed as long as possible. Even when such a judgement has been passed one must never cease to question whether the judgement is right, and how many individual members of the collective enemy it is legitimate to include. The moralising that takes place does not necessarily take these circumstances into consideration, and induces great expense. What follows is an intensification of what is at stake. As a consequence of moralisation, for both parties, war becomes a question of who we are. It is less concerned with specific war goals such as redistribution of material resources among different groups in the society or the securing of strategically important resources. It is more difficult to negotiate with an opponent about who 'we' are than it is about specific resources, for the simple reason that resources can be 
divided into smaller pieces, about which one can reach a compromise. In contrast, one cannot divide identities in the same way.

If war is going to be a case study in how humanity itself is emerging as a political community, then this is an instance of good fighting evil, and it is of little point to ask how the war goals are perceived by the opponent, because he has already been cast in the subject position of evil itself. The thought behind a 'just war' has the disadvantage that one is not continuously evaluating the way in which the other side looks at the world. One knows the nature of the evil, and one knows that it is impossible to influence evil intent by arguments, but only by means of resolute action such as war.

\section{The other side}

A discourse that has no subject position for others than 'humanity' is a totalising discourse. It is always worth asking where the other is, and how she perceives the relationship. The case of Yugoslavia can be no exception. When one is to defend the old order, such a defence manifests itself in the purest form. Milosevic's Yugoslavia illustrates for us the ultimate consequences of a national doctrine that rejects everything and anyone which and who does not belong to that nation. However, before we reject this as unfamiliar, we should remember that this was a creative part of the European political order for 200 years. It is pathos in the war in Kosovo. The old has no possibility of victory. As Karl Otto Hondrich stated in Die Zeit: the Serb military are not permitted to fight on equal terms, and therefore it is only by not retreating that they can win the respect and dignity that fighting embodies. ${ }^{13}$

Sergei Medvedev notes in the first chapter of this book that 'Milosevic is a classic sovereign'. Indeed, the notions of sovereignty, the right of selfdetermination and the right to determine one's own internal affairs, dominate the Serbian discourse. Milosevic could hardly be expected to enjoy the fading of that pivotal principle of the classical European state system: the immunity of sovereigns. In the Serbian discourse, the fading of that principle, from the aftermath of the Second World War at the tribunals of Tokyo and Nuremberg via the formation of a body of humanitarian law to the founding of the International Criminal Court and beyond, has been determinedly discounted. NATO's policy is portrayed as that of an aggressor, culminating in an intrusion into other people's affairs. The main pillar in the Serbian national policy is the nation state, which they want to protect against interference and aggression from the outside. There is, of course, the problem of where to draw the borders for this nation state: for many Serbs, the Serbian 'we' is connected to Greater Serbia. But, aggression against areas outside Greater Serbia has never been on the agenda. The often drawn parallel with Hitler therefore has a fatal weakness, namely that 
it has never been a question of Serbia attacking the great powers of Europe or of instituting a new regime type throughout Europe. On the contrary, Milosevic and most of the Serbs argue from a set of fundamental conceptions that has been common in Europe for more than a century, namely that political division in the world runs between the 'we' in one's own nation state, on the one side, and all the others outside, on the other.

As recently as twenty years ago, Vietnam intervened in the internal affairs of Cambodia, overthrowing Pol Pot and his regime and establishing its own man in his place. It did not matter that Pol Pot as ruling head had several million human lives on his consciousness; the united West condemned Vietnam's conduct. The murder of his own citizens was therefore not accorded special political weight. This occurrence in Cambodia in 1979 serves as an example of the paucity of humanitarian intervention over the past century. Obviously, the situation has now changed. The new NATO has appeared as the flag bearer, restricting violence and defining order in the world. This new order is post-national, and must be understood as such. In opposition stands the old national state order, Milosevic and the old order proponents. One can perhaps even talk about this in a social context, Yugoslavia standing for the old order and NATO and the West for the new. All over Central and Eastern Europe people and states have to decide whether they want to submit to the post-national order, global capitalism and multiethnic politics, or whether they will remain within the old nation state. Perhaps one of the reasons why Milosevic had so long enjoyed the support of the Serbs was the fact that the lifestyle resulting from the Western hegemony did not necessarily appeal to the majority of the Serbs.

\section{Legitimising weapons, targets and victims}

If the subject who wages war is 'humanity', then a representation of the opponent as non-human lies close at hand. At least, it invites a dehumanising gaze at the enemy. If the enemy is defined by such a dehumanising gaze, it may have consequences for what one considers to be the legitimate means in fighting that enemy. The less human the enemy, the fewer the holds barred in picking your weapons and your strategy.

After Kosovo, the means employed in warfare have become an important issue. A so-called 'revolution in military affairs', or rather a revolution in American military affairs, is taking place. New sorts of weapons have emerged; new constellations are presented for the organisation of military personnel. This debate has taken place in a field where every weapons system and every organisational model has its acronym. Therefore, there are few people who have the opportunity of including this development in their comprehension of the world. This concerns not least the politicians, who during the Cold War used to leave the military aspects of politics to the 
military, and so felt no urgent need to be updated in what was happening in the defence laboratories. But, as Kosovo shows, developments in areas such as aviation power came to play a crucial role in how the war developed. From the White House one could send a message to the Pentagon saying that one was going to bomb without losing either personnel or planes. The military simulated several war operations to estimate the minimum height for planes in order not to be shot down by Serbian air defence. An altitude of 15,000 feet was estimated to be the minimum, an appraisal that turned out to be technically correct given the mission: although one plane had been shot down, not a single soldier had lost his life.

During the Gulf War, in which aviation power also dominated, the French philosopher Jean Baudrillard wrote a set of controversial articles about the conflict, saying that the war had already taken place, or alternatively, that it did not take place at all. ${ }^{14}$ This was a familiar French provocation. Few people, particularly outside of the Left Bank, made an attempt to try to understand what he meant by this. After Kosovo it may be easier to comprehend. One aspect of war that is noteworthy nowadays is that it takes place in advance, as simulated exercises. There is, of course, nothing new about practising war. However, the planning in detail and the simulation of operations in advance - which is made possible by new communication technology - are new. This new technology can easily lead to a planning hubris, the thought that the future can be predicted in detail. Even the air raids on Kosovo became simply a routine repetition of something that originally had been done in a closed computer system in the Pentagon. It was in Washington, and not in the air above Kosovo, that it was decided which sorts of bombs should be dropped where and when.

Consequently, one could argue that the war in Kosovo had already taken place - inside the Pentagon. It becomes really problematical, however, when one also can claim that the war between Yugoslavia and NATO in Kosovo never took place. This must be understood in the sense of one antagonist using his superior technology to win a victory without getting involved in live warfare. The actions and battles which were fought did not happen between NATO and Yugoslavia, but between Yugoslavia and a third party. What was happening on the ground and in the air were, of course, closely connected. They were probably connected in the sense that the killings would not have been possible in such a form and to such a degree, had it not been for the success of the air war. And yet, they were two quite different phenomena.

The fact that the Americans had access to technology of such superiority that they did not have to conduct war in the sense of real fighting is problematical in a number of ways. In the first place, it breaks with our conception of the kinds of weapons that are legitimate in war. In the history of Europe, there have been several conceptions of the means which are legitimate in particular circumstances. For example, in the late Middle Ages, 
it was good Latin that one could use squared bullets against infidels, whereas against a Christian enemy one should use a round bullet. ${ }^{15}$ In this area, international law (as ius in bello) has played a crucial role. We have had a debate on the legitimate bombing targets. We have, not least in connection with the Vietnam War, had earlier debates on the legitimate bombs. We need another such debate. The point is not to abolish bombing as such, but to restrict the kinds of bombs one should be able to use. This needs to be done in order that the Air Force officers, and those of us who find ourselves on the bombing side, can look at ourselves in the mirror the next day.

Bombs are technology, and an approach to the problem that considers which kinds of technology the fighters should be using is a necessary part of our conversation on war. There is, however, another aspect to the way in which the war was conducted, one that gives rise to even greater anxiety. It is the question of military decisions taken by the politicians. In the Kosovo war, it was asserted by Alliance politicians collectively that a loss of personnel could not be tolerated by public opinion. As a consequence, aircraft flew higher than the military would have preferred. The consequence of flying higher was that the bombing was less precise, and, as a result, the number of civilian casualities was higher than it would have been at lesser altitude. This tendency to an ever-increasing distance between, in this case, the pilot and the target, and the multiplication of standard procedures, has reached new heights. How should one comprehend this? Is it possible to find a proportion, so that one of 'our' pilots, for instance, should be worth 5,000 civilian lives? That would be a way of thinking which would totally break with our fundamental conception about human worth. If one assumes, however, that politicians are elected and are responsible to an electorate which demands that war be conducted without loss, this logic is sequential.

The free exchange of views in our societies makes it, at least in this case, more difficult to reduce violence, not easier. When civilians present the case so that it seems as if it is the pilot's own will (or lack thereof) to sacrifice his life in operations, they grasp an important part of the problem. People who have chosen to become officers have chosen a kind of lifestyle in which something - it can be a number of things - is more important for them than this extra risk they take by choosing the military way of life. The responsibility of politicians to their own officers and other volunteers is thereby associated with formulating clearly defined goals for military action, and making it possible for the officers to execute these in a way which they see as professionally justifiable. It is not the responsibility of politicians to entirely exempt them from the possibility of dying. When politicians insist that their own personnel are not going to die, this cannot be understood as some kind of concern for these people. Rather, it must be perceived as an attempt to avoid the political problems induced by a critical public opinion.

A no-own-losses war has indeed increased the civilian casualties which it was seeking to prevent. The political reality is that the expense of suffering 
losses has become so high that the temptation to let other people die instead is almost irresistible. In this case we face two concrete questions: first, whether it was immoral to start a war at all; and, second, whether it was immoral to start a war in the way it was started, namely without a ground invasion, i.e. in a way that showed no intention to accept own losses. Conducting a war without a willingness to sacrifice life seems especially problematic. And yet nothing is easier to understand politically than politicians wanting to do everything to reduce damage to themselves among their own electorate.

We have here an especially difficult case of a general problem, namely how to balance our own citizen's rights against the rights of other parts of humanity. The old thinking used to hold that the nation state's sovereignty made it relatively easy to put aside the rights of the rest of the world. In Kosovo, we faced the paradoxical situation in which bombing was legitimised by breaking this logic. What happened did not involve Yugoslavia's internal affairs, but above all human affairs. By choosing bombing, however, we opted to save lives on 'our' side by killing even more of 'them'. What has emerged is thereby a bargaining game about how war should be comprehended after Kosovo. We do not agree with ourselves at this juncture. If we want to achieve a way of conducting war in which the use of violence is mostly restricted, the war in Kosovo does not seem to be much of an ideal.

Those who revel in the fact that not a single American life was lost in Kosovo contribute to the assertion that war simply is a form of politics, along with other instruments like economic aid. Air war becomes a policy option, to which one can have recourse whenever one fancies, sometimes before all of the other alternatives have been tried. If this is to become the place of war in the political arena, it is very unfortunate. Niccolò Machiavelli argued in his Discourses that in war there is always a tendency to build quickly ${ }^{16} \mathrm{He}$ suggested that the bare existence of fortresses could fool the Prince to use this technology to keep the population in check. In the same way, one can today issue a specific warning to Western politicians and the military not to build too many of these advanced fighting planes, because the mere existence of these superb machines tempts those in power to use them as ordinary political instruments. The wise Prince restricts violence by choosing more indirect tools for ruling.

\section{Conclusion}

The three questions put in the beginning - which actors are seen as legitimate wagers of war, over which issues it is legitimate to go to war and what are the legitimate ways of waging war? - have a certain common denominator. That is, 'humanity' may exist as a political notion, and increasingly as a legal concept, but it is not (yet?) strong enough to carry the burden placed 
upon it by NATO countries of legitimising the waging of war in Kosovo. As Jean-François Lyotard has argued:

The 'reason to die' always forms the bond of the we. The paradox of the order to die is that the name of its addressee, if he or she obeys the order, can never again figure upon the addressor instance of subsequence, direct phrases, and in particular of normative phrases like 'I decree as a norm that . . .' 17

States could pose as the legitimate wagers of war so long as that right had been conferred upon them by the community of states acting in unison, as legislators and guarantors of international law. The question, therefore, is whether it was humanity acting through the security community of NATO that was waging war, or whether it was NATO member states acting together as an alliance. A related problem is the dogged unwillingness of the entities involved actually to suffer losses in the process. 'Humanity' may be invoked as a legitimising speech act inside the discourse of the international law, but it spectacularly fails to legitimise the violence which follows its invocation. Serbia's attempts to legitimise its stance as a warring state defending the idea of state sovereignty was represented as an anachronism. Indeed, in Kosovo, the end of the legitimate warring state was at stake. Where is the political entity that may legitimately speak in the name of humanity?

\section{Notes}

1 Michel Foucault, 'On the Genealogy of Ethics', in Paul Rabinow (ed.), The Foucault Reader (New York, Pantheon, 1984), p. 236.

2 Carl Schmitt, Der Begriff des Politischen: Text von 1932 mit einem Vorwort und drei Collarien (Berlin, Duncker \& Humblot, 1963).

3 In his piece, Ole Wæver also noted that 'Balkanization is a tool for legitimizing an international order without a named enemy': Ole Wæver 'Securitization and Desecuritization', in Ronnie D. Lipschutz (ed.), On Security (New York, Columbia University Press, 1995), p. 67. If so, then the Kosovo war de-Balkanised the Balkans and the world order. For a general discussion, compare with Barry Buzan, 'Rethinking Security after the Cold War', Cooperation and Conflict, vol. 32, no. 1 (March 1997).

4 Buzan, 'Rethinking Security', p. 14.

5 Iver B. Neumann, 'Identity and the Outbreak of War', in Ho-Won Jeung (ed.), The New Agenda for Peace Research (Aldershot, Ashgate, 1999), and Lene Hansen, 'The Little Mermaid's Silent Security Dilemma and the Absence of Gender in the Copenhagen School', Millennium, vol. 29, no. 2 (2000), pp. 285-306.

6 Richardson suggests 317, the Correlate of Wars project suggests 1,000 dead; for a discussion of the numerical criteria see Håkan Wiberg, Konfliktteori och fredsforskning (Stockholm, Scandinavian University Books, 1976).

7 Quoted in Wæver, 'Securitization and Desecuritization', p. 53.

8 Compare with the discussion of Bosnia in Espen Barth Eide, "Conflict entrepreneurship": A Few Post-Yugoslav Reflections on the "Art” of Waging Civil War', 
in Engaging the Challenges of Tomorrow: Adjusting Humanitarian Interventions to the Character of Future Conflict (Oslo, Norwegian Institute of International Affairs, 1997).

9 Milovan Djilas, Memoirs of a Revolutionary (New York, Harcourt, Brace, Jovanovich, 1973).

10 Benjamin R. Barber, Jihad vs. McWorld. How Globalism and Tribalism are Reshaping the World (New York, Ballantine, 1996).

11 This holds, at least for the time being; Michael Jackson may at some later point turn out to have been a trendsetter.

12 Michael Walzer, Just and Unjust Wars: A Moral Argument with Historical Examples (London, Penguin, 1980).

13 Die Zeit, 27 May 1999; also see Behnke's chapter in this volume.

14 Reprinted in Jean Baudrillard, La guerre du golfe n'a pas eu lieu (Paris, Galilée, 1991). Baudrillard waged his campaign not only on the stratospheric level of philosophy, but at the level of the actual: 'Les Presses de la Cité invited me to go to the Gulf and cover the war. They were going to give me everything: money, documents, flights, etc. I live in the virtual. Send me into the real, and I don't know what to do. And, anyway, what more would I have seen? Those who went there saw nothing, only odds and ends.' Baudrillard in Mike Gane (ed.), Baudrillard Live: Selected Interviews (London, Routledge, 1991), p. 188.

15 R.J. Vincent, Human Rights and International Relations (Cambridge, Cambridge University Press, 1986).

16 Niccolò Machiavelli, The Discourses (London, Penguin, 1970).

17 Jean-François Lyotard, The Differend: Phrases in Dispute (Minneapolis, University of Minnesota Press, 1988), p. 100, note 156; compare pp. 152-5. 